\title{
Assessment of creativity based learning environment for major instrument courses: A case study of Buca Faculty of Education, Department of Music Education ${ }^{1}$
}

\author{
Asli Kaya ${ }^{2}$ \\ Sermin Bilen ${ }^{3}$
}

\begin{abstract}
The development of the creative potential of individuals is considered to be one of the requirements of modern education. As in all areas, the development of students' creative potential is also among the objectives of education programs in music education. The ability of music teachers to achieve this objective and create creative learning environments for their own students' creative potential, is dependent on their training in such a learning environment.

In this regard, one aim of this research is to develop a scale which can assess the creativity based learning environment for Major Instrument courses carried out within faculties of Education, Fine Arts Education, Music Education programs. The second aim is to evaluate using this scale, the creativity based learning environment for the Major Instrument courses carried out in the Buca Faculty of Education, Department of Music Education.

The scale was developed as 5 point Likert scale and was applied to 528 students who were studying in the Faculty of Education, Fine Arts Education, Music Education Department in several universities during the 2012-2013 academic year. The data was analyzed with SPSS 16.0. Additionally, the LISREL 8.8 program was used for confirmatory factor analyses.

After items distorting the factor structure were removed, the scale was left with 12 items. The scale's Cronbach Alpha value was determined as .928. At the end of the confirmatory factor analysis the level of fit criteria were found to be; $\chi^{2} / s d: 4.0$; RMSEA: .07; NNFI: .98; CFI: .98; GFI: .94. The data show that the scale in general has an improved fit.

The scale was applied to 72 students studying at the Buca Faculty of Education, Fine Arts Education, Music Education Department in the 2014-2015 academic year with the aim of determining the Major Instrument courses' learning environments. The scale's Cronbach Alpha value was determined as .948.

Responses by students taking Major Instrument courses showed that lessons were carried out in creativity based $(\bar{x}=3.95)$ and positive learning environments $(\bar{x}=4.25)$ in which the students' creativity was supported $(\bar{x}=3.73)$. With regard to the creativity based learning environment, Major Instrument Guitar courses presented the highest level $(\bar{x}=4.55)$ and Major Instrument Baglama course, the lowest ( $\bar{x}=2.95)$.
\end{abstract}

Keywords: Music teacher training; major instrument courses; creative learning environment; scale development.

\footnotetext{
1 The article was presented at ERPA International Congresses on Education 2015.

2 Res. Asst., Dokuz Eylul University, Buca Faculty of Education, Department of Music Education, asli.kaya@deu.edu.tr.

3 Asst. Prof. Dr., Dokuz Eylul University, Buca Faculty of Education, Department of Music Education, sermin.bilen@deu.edu.tr.
} 
Kaya, A., \& Bilen, S. (2016). Assessment of creativity based learning environment for major instrument courses: A case study of Buca Faculty of Education, Department of Music Education. Journal of Human Sciences, 13(2), 31023111. doi:10.14687/ihs.v13i2.3873

\section{Introduction}

Creativity takes part in every aspect of human life as well as human evolution (San, 2004: 14). Today, it is acknowledged as one of the most crucial requirements of progress. Adaptability to new technologies and information and the ability to generate information depend on individuals who can make use of this creative power (Sternberg, 1995). It follows that the educational system should also promote and develop creativity of individuals. "The aim of education is to create people who can put forward new things, not merely repeat what previous generations have done. Piaget maintains that creative, inventive and inquisitive people are those who have a questioning mind and who do not take every fact presented to them for granted" (Sungur, 1992: 41).

Educators, being the most crucial factors in the cultivation of creative individuals are required to possess the qualifications necessary to achieve this goal. The level of creativity, in other words, the power of fluent, flexible and original thinking that they possess, determines the level of the teaching-learning environment that is to influence the creativity of students and the level of guidance in development of creativity (Yenilmez and Yolcu, 2007). Buyurgan and Buyurgan (2007: 30) maintain that "providing the necessary infrastructure (environment, time, equipment, motivation, information or access to information) that is required for creative thinking or output production" is among the qualities that should be met by teachers for development of the creativity of their students. Rule-based and rigid approaches that over-criticise and discourage students are thought to inhibit creativity (Sungur, 1992: 46, as cited in Buyurgan and Buyurgan, 2007: 31).

Among the general goals cited for the Elementary Music Courses curriculum can be found the statement "to develop the creativity and talents of students through production of music" (Milli Eğitim Bakanlı̆̆1-MEB, 2006: 6). The Secondary level Music Courses curriculum aims to train individuals to achieve self-expression through interpretation of music (by singing, playing and listening); creativity through improvising and composing; ability to think and create through musical perception and knowledge; and the ability to read and write using musical notation (MEB, 2009: 12).

It is of crucial importance for the quality of music education in schools that music teachers who are expected to achieve these goals are themselves educated in a creative learning environment.

The Music Teacher Education curricula aim to produce qualified teachers who have sufficient theoretical knowledge of music and can transform this knowledge to the necessary skills through association with other areas of music; who have a wide-ranged repertoire of educational music and can put this repertoire into use with respect to intended goal; who possess creative thinking capabilities and can pass these on to their students; who possess social, professional and ethical responsibility and conscience; and who can efficiently use developing technology and apply this technology in teaching music (Dokuz Eylül Üniversitesi, 2015a, January 12).

Major Instrument courses aim to provide students with instrument playing techniques, knowledge and skills. The students are also expected to reach a level of competency through which they can pass on their knowledge and skills to their own students and plan creative activities in accordance with their playing skills and level (Yükseköğretim Kurulu, 2007: 177-202; Dokuz Eylül Üniversitesi, 2015b, January 12). In addition, this courses are taught one hour per week throughout four years. In this courses consist of different instruments. Such as violin, viola, violoncello, contrabass, flute, guitar, voice, baglama. And also these instruments are selected according to the appropriateness of the instrument of each student. 
Kaya, A., \& Bilen, S. (2016). Assessment of creativity based learning environment for major instrument courses: A case study of Buca Faculty of Education, Department of Music Education. Journal of Human Sciences, 13(2), 31023111. doi:10.14687/ihs.v13i2.3873

\section{Purpose}

The purpose of this study to develop a "Creativity Based Learning Environment Assessment Scale" for Major Instrument courses carried out within Music Education departments of education faculties' Fine Arts Education divisions; and to evaluate the learning environment of Major Instrument courses carried out within the Buca Faculty of Education, Department of Music Education.

\section{Method and material}

The development process of the "Creativity Based Learning Environment Assessment Scale" intended for Major Instrument courses consisted of the following stages:

In the first stage, an item pool was formed as a result of literature review related to the development and improvement of creativity and creative learning environments. Then, a 5 point Likert scale draft was designed with regard to common characteristics of items, gathered under the factors positive learning environment, creativity based and negative impact of environment. The draft scale was later presented to specialists and necessary amendments were made according to their feedback. The scale was also subject to several other amendments, in response to feedback from 5 university students to whom it was applied as a pilot trial.

The scale in its ultimate form was applied to 600 students who were studying in the 20122013 academic year at education faculties, Music Education departments of various universities. After elimination of invalid data, the research group was left with 528 students. The data was analyzed using programs SPSS 16.0 and LISREL 8.8. The distribution of participants of the research group according to university, level and gender is shown in Table 1.

Table 1

Distribution of the research group by university, level and gender

\begin{tabular}{|c|c|c|c|}
\hline \multicolumn{2}{|l|}{ University } & \multirow{2}{*}{$\begin{array}{c}\mathbf{n} \\
92\end{array}$} & \multirow{2}{*}{$\begin{array}{c}\% \\
17.4\end{array}$} \\
\hline Balikesir & & & \\
\hline Muğla S1tk1 Koçman & & 64 & 12.1 \\
\hline Ondokuz Mayıs & & 66 & 12.5 \\
\hline Harran & & 72 & 13.6 \\
\hline Yüzüncü Yıl & & 52 & 9.8 \\
\hline Dokuz Eylül & & 70 & 13.3 \\
\hline Pamukkale & & 65 & 12.3 \\
\hline Adnan Menderes & & 47 & 8.9 \\
\hline & Total & 528 & 100 \\
\hline Level & & $\mathbf{n}$ & $\%$ \\
\hline $1^{\text {st }}$ Year & & 91 & 17.2 \\
\hline $2^{\text {nd }}$ Year & & 137 & 25.9 \\
\hline $3^{\text {rd }}$ Year & & 151 & 28.6 \\
\hline $4^{\text {th }}$ Year & & 149 & 28.2 \\
\hline & Total & 528 & 100 \\
\hline Gender & & $\mathbf{n}$ & $\%$ \\
\hline Female & & 298 & 56.4 \\
\hline Male & & 230 & 43.6 \\
\hline & Total & 528 & 100 \\
\hline
\end{tabular}


Kaya, A., \& Bilen, S. (2016). Assessment of creativity based learning environment for major instrument courses: A case study of Buca Faculty of Education, Department of Music Education. Journal of Human Sciences, 13(2), 31023111. doi:10.14687/ihs.v13i2.3873

\section{Findings}

To evaluate the construct validity of the scale, exploratory and confirmatory factor analysis were performed.

The variables are summarized and determined with the exploratory factor analysis and also it is used at the beginning of the research. Whereas the confirmatory factor analysis is used in the next stage of the research to test the theory about the latent variables. And also construct validity coefficients (fit indices) are produced (Çokluk et al., 2012: 284-285).

The exploratory factor analysis was performed with the aim of transforming the ultimate 23-item measurement tool which was designed to evaluate the creativity based learning environment for Major Instrument courses, into a tool which can measure the maximum number of characteristics with the minimum number of items. The exploratory factor analysis is a procedure which aims to find factors on the basis of relationships between variables (Büyüköztürk, 2009: 123).

As a result of the analysis, items disrupting the factor structure $(4,7,8,14,18,19,21,22$, $23)$, having low communalities $(<.50)$ were eliminated from the variable combination and factor analysis was repeated. Item factor loadings (rotated components analysis) can be found in Table 2.

Table 2

\begin{tabular}{cccc}
\multicolumn{4}{c}{ Rotated components matrix } \\
\hline Items & Factor 1 & Factor 2 & Factor 3 \\
\hline 1 & .805 & & \\
2 & .862 & & \\
3 & .800 & & \\
6 & .748 & & \\
17 & .609 & .784 & \\
9 & & .795 & \\
10 & & .838 & \\
11 & & .850 & \\
12 & & .698 & .847 \\
13 & & .663 & .893 \\
15 & & .618 \\
20 & & & \\
5 & & Bartlett Test $\mathrm{p}=.000$ \\
16 & & \multicolumn{4}{c}{} \\
\hline KMO = .921
\end{tabular}

According to the rotated components matrix shown in Table 2, the factor loadings of items included under the three factors are: between .609 and .862 for Factor 1; between .618 and .850 for Factor 2; .847 and .893 for Factor 3. The total variance explained by all three factors is $69 \%$.

The KMO and Bartlett test results show that the scale is appropriate for exploratory factor analysis [.921> .50] and that there is a high correlation between factors $[\mathrm{p}<.05]$. However, since Factor 3 comprised only 2 items, items 5 and 16 were excluded from the variable combination and factor analysis was repeated. The factor loadings of the factor analysis (rotated components matrix) performed with the remaining 12 items is shown in Table 3. 
Kaya, A., \& Bilen, S. (2016). Assessment of creativity based learning environment for major instrument courses: A case study of Buca Faculty of Education, Department of Music Education. Journal of Human Sciences, 13(2), $3102-$ 3111. doi:10.14687/jhs.v13i2.3873

Table 3

Rotated components matrix

\begin{tabular}{ccc}
\hline Items & Factor 1 & Factor 2 \\
\hline 1 & .816 & \\
2 & .882 & \\
3 & .829 & \\
6 & .765 & \\
17 & .592 & .779 \\
9 & & .790 \\
10 & & .833 \\
11 & & .846 \\
12 & & .694 \\
13 & & .662 \\
15 & & .616 \\
20 & \multicolumn{2}{c}{ Bartlett Test $\mathrm{p}=.000$} \\
\hline KMO $=.934$ &
\end{tabular}

The rotated components matrix shown in Table 3 demonstrates that the factor loadings of items under Factor 1 are between .592 and .882; and those under Factor 2 are between .616 and .846. The total variance explained by the two factors is $67 \%$. The distribution of scale items with regard to factors is as follows:

- Factor 1 (positive learning environment): items 1, 2, 3, 6 and 17.

- Factor 2 (creativity based): items 9, 10, 11, 12, 13, 15 and 20.

The KMO and Bartlett test results show that the scale is appropriate for exploratory factor analysis [.934> .50] and that there is a high correlation between factors $[\mathrm{p}<.05]$.

A first order confirmatory factor analysis was carried out to test the congruency of factors determined by the exploratory factor analysis, with determined factor structures. A confirmatory factor analysis is the procedure by which a former hypothesis or theory on the relationship between variables can be tested (Büyüköztürk, 2009: 123).

The two factors (latent variable) determined by the exploratory factor analysis and the ratio by which the basic (observed) variables describing these factors represent them, together with their standardized coefficients are shown in Figure 1. 
Kaya, A., \& Bilen, S. (2016). Assessment of creativity based learning environment for major instrument courses: A case study of Buca Faculty of Education, Department of Music Education. Journal of Human Sciences, 13(2), 31023111. doi:10.14687/ihs.v13i2.3873

\section{Figure 1}

Standardized path coefficient diagram

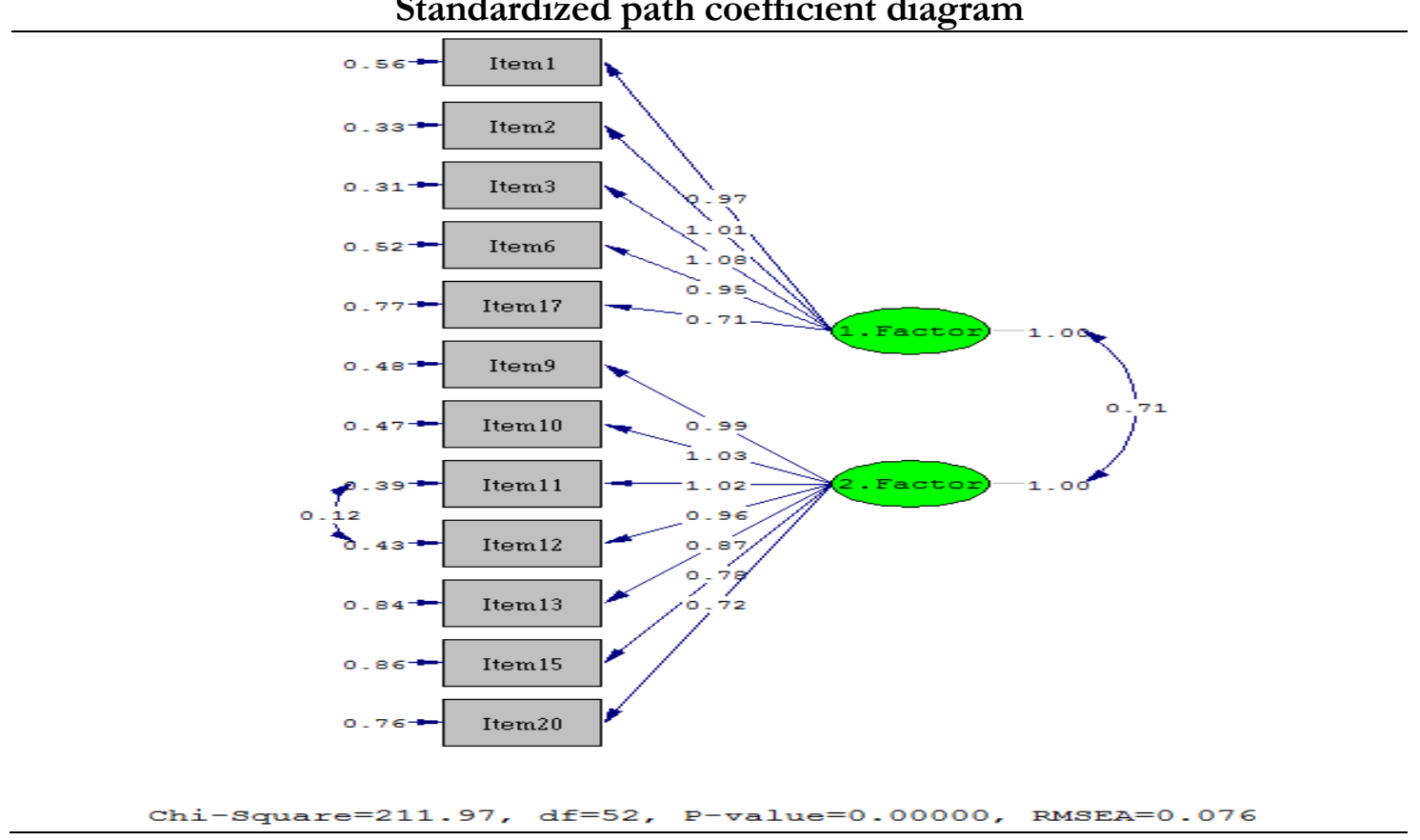

According to the first order confirmatory factor analysis, the ratio between chi-square and degree of freedom is $\chi^{2} / s d: 4.0$ and chi-square has a significance value of .00. In large samples $\chi^{2} / s d$ ratios less than 3 correspond to perfect concordance, and those less than 5 , to moderate concordance (Kline, 2005; Sümer 2000, as cited in Çokluk et al., 2012: 307).

The fit index values of the scale are: RMSEA: .07; NNFI: .98; CFI: .98; GFI: .94. These values show that the scale in general has an acceptable fit index. (Çokluk et al., 2012: 307, 312).

Since the scale consisted of two factors, a second order confirmatory factor analysis was not conducted. This is a confirmatory factor analysis model designed to define the second order factor which directly affects the first order factor (Çokluk et al., 2012: 281). In second order factor analysis, defining the second order requires at least three first order factors. Otherwise, the direct effect of the second order on the first might be inadequately defined (Kline, 2005, as cited in Çokluk et al., 2012: 282).

A simple linear correlation (Pearson's product moment correlation) was carried out to assess the degree and direction of correlation between factors. The result of the correlation is shown in Table 4.

Table 4

Correlation between factors

\begin{tabular}{ccc}
\hline & Positive Learning Environment & Creativity Based \\
\hline Positive Learning Environment & 1 & $.668^{* *}$ \\
Creativity Based & $.668^{* *}$ & 1 \\
\hline
\end{tabular}

The data in Table 4 show that there is a positive and significant correlation between the positive learning environment and creativity based $[\mathrm{r}=.668, \mathrm{p}<.01]$.

The general reliability coefficient values for the factors and scale can be found in Table 5 . The Cronbach Alpha reliability coefficient is an indication that a single measurement can be highly consistent in itself, removing the need for additional applications (Can, 2013: 340). 
Kaya, A., \& Bilen, S. (2016). Assessment of creativity based learning environment for major instrument courses: A case study of Buca Faculty of Education, Department of Music Education. Journal of Human Sciences, 13(2), 31023111. doi:10.14687/jhs.v13i2.3873

Table 5

Reliability coefficients

\begin{tabular}{lccc}
\hline \multicolumn{1}{c}{ Factors } & $\boldsymbol{\alpha}$ & \multicolumn{1}{c}{ Item number } \\
\hline Positive Learning Environment & .895 & 5 \\
Creativity Based & & .905 & 7 \\
& General & .928 & 12 \\
\hline
\end{tabular}

It can be seen from Table 5 that the general reliability coefficient of the scale is .928 ; with the positive learning environment component having a reliability coefficient of .895 , and the creativity based component, of .905. This result shows that measurements have a high level of reliability $[.90 \leq \alpha<1]$.

The study in which the Major Instrument courses carried out in the Buca Faculty of Education, Department of Music Education were evaluated in relation to the learning environment, was performed using the "Creativity Based Learning Environment Assessment Scale" designed for Major Instrument Courses.

The scale was applied to $2^{\text {nd }}, 3^{\text {rd }}$ and $4^{\text {th }}$ year students $(\mathrm{n}=72)$ studying at the Buca Faculty of Education, Department of Music education during the 2014-2015 academic year. $1^{\text {st }}$ year students were excluded from the study since they had been taking the course for only one semester. The distribution of participants of the research group by gender, major instrument and level is shown in Table 6.

Table 6

Distribution of the research group by gender, major instrument and level

\begin{tabular}{lccc}
\hline \multicolumn{1}{c}{ Gender } & & $\mathbf{n}$ & $\mathbf{0}$ \\
\hline Female & & 45 & 62.5 \\
Male & & 27 & 37.5 \\
& Total & 72 & 100 \\
\hline \multicolumn{1}{c}{ Major Instrument } & $\mathbf{n}$ & $\mathbf{0}$ \\
\hline Violin & 15 & 20.8 \\
Viola & 4 & 5.6 \\
Violoncello & 9 & 12.5 \\
Contrabass & 2 & 2.8 \\
Flute & 11 & 15.3 \\
Guitar & & 6 & 8.3 \\
Voice & & 21 & 29.2 \\
Baglama & & 4 & 5.6 \\
& Total & 72 & 100 \\
\hline & & $\mathbf{n}$ & $\mathbf{0}$ \\
\hline $2^{\text {nd }}$ Year & Level & 29 & 40.3 \\
$3^{\text {rd }}$ Year & & 22 & 30.6 \\
$4^{\text {th }}$ Year & & 21 & 29.2 \\
& & 72 & 100 \\
\hline
\end{tabular}

The data in Table 6 demonstrate that within the research group consisting of $62.5 \%$ female and $37.5 \%$ male students, voice students represented the highest percentage $(29.2 \%)$ and contrabass students, the lowest (2.8\%). It can also be seen that $40.3 \%$ of the students were studying in $2^{\text {nd }}$ Year, $30.6 \%$ in $3^{\text {rd }}$ Year and $29.2 \%$ in $4^{\text {th }}$ Year. 
Kaya, A., \& Bilen, S. (2016). Assessment of creativity based learning environment for major instrument courses: A case study of Buca Faculty of Education, Department of Music Education. Journal of Human Sciences, 13(2), 31023111. doi:10.14687/ihs.v13i2.3873

Table 7 shows the reliability of measurements via the Cronbach Alpha coefficient.

Table 7

Reliability coefficients

\begin{tabular}{llcc}
\hline \multicolumn{1}{c}{ Factors } & & $\boldsymbol{\alpha}$ & Item number \\
\hline Positive & Learning & .913 & 5 \\
Environment & & & \\
Creativity Based & & .927 & 7 \\
& General & .948 & 12 \\
\hline
\end{tabular}

According to the data in Table 7, the general reliability coefficient value of the scale is .948; the reliability coefficient value for the positive learning environment component is .913 and for the creativity based component, .927 . These results indicate that the measurements have a high level of reliability $[.90 \leq \alpha<1]$.

The responses of the research group to the "Creativity Based Learning Environment Assessment Scale" in relation to gender, major instrument and level is shown in Table 8 with their respective average values.

Table 8

Average values of responses to scale by gender, major instrument and level

\begin{tabular}{|c|c|c|c|c|}
\hline & & $\begin{array}{l}\text { Positive Learning } \\
\text { Environment }\end{array}$ & $\begin{array}{c}\text { Creativity } \\
\text { Based }\end{array}$ & General \\
\hline Gender & $\mathbf{n}$ & $\bar{x}$ & $\bar{x}$ & $\bar{x}$ \\
\hline Female & 45 & 4.22 & 3.66 & 3.89 \\
\hline Male & 27 & 4.30 & 3.85 & 4.04 \\
\hline Major Instrument & $\mathbf{n}$ & $\bar{x}$ & $\bar{x}$ & $\bar{x}$ \\
\hline Violin & 15 & 4.02 & 3.41 & 3.67 \\
\hline Viola & 4 & 4.30 & 3.85 & 4.04 \\
\hline Violoncello & 9 & 3.73 & 3.53 & 3.62 \\
\hline Contrabass & 2 & 4.55 & 3.82 & 4.12 \\
\hline Flute & 11 & 4.36 & 3.67 & 3.96 \\
\hline Guitar & 6 & 4.90 & 4.30 & 4.55 \\
\hline Voice & 21 & 4.44 & 3.95 & 4.15 \\
\hline Baglama & 4 & 3.10 & 2.85 & 2.95 \\
\hline Level & $\mathbf{n}$ & $\bar{x}$ & $\bar{x}$ & $\bar{x}$ \\
\hline $2^{\text {nd }}$ Year & 29 & 4.23 & 3.56 & 3.84 \\
\hline $3^{\text {rd }}$ Year & 22 & 4.23 & 3.74 & 3.94 \\
\hline $4^{\text {th }}$ Year & 21 & 4.30 & 3.95 & 4.10 \\
\hline Total & 72 & 4.25 & 3.73 & 3.95 \\
\hline
\end{tabular}

The data in Table 8 show that average value of responses of females in the research group was 3.89 and that of males is 4.04 . The maximum average value of 4.55 corresponds to students with guitar as their major instrument, whereas the minimum average value of 2.95 corresponds to students with baglama as their major instrument. The averages for $2^{\text {nd }}, 3^{\text {rd }}$ and $4^{\text {th }}$ year students were $3.84,3.94$ and 4.10 respectively.

The average value for responses of the research group in general was found to be 3.95; with the positive learning environment component average being 4.25 and creativity based component, 3.73 . 
Kaya, A., \& Bilen, S. (2016). Assessment of creativity based learning environment for major instrument courses: A case study of Buca Faculty of Education, Department of Music Education. Journal of Human Sciences, 13(2), 31023111. doi:10.14687/ihs.v13i2.3873

\section{Results}

The basic results obtained through the development of a "Creativity Based Learning Environment Assessment Scale" intended for Major Instrument courses carried out in Music Education departments within faculties of Education, Fine Arts Education divisions, are as follows:

- The 12-item scale, according to the KMO and Bartlett test results is appropriate for exploratory factor analysis [.934>.50] and there is a high level of correlation between variables $[\mathrm{p}<.05]$.

- The factor loadings for the two factors included in the scale range from .592 to .846. The total variance explained by the factors is $67 \%$.

- The confirmatory factor analysis reveals that the ratio between chi-square and degrees of freedom is $\chi^{2} / s d: 4.0$ and chi-square has a significance value of .00 . Fit index values are as follows: RMSEA: .07; NNFI: .98; CFI: .98; GFI: .94. The scale has in general an acceptable fit index.

- The results obtained from correlation between factors imply that there exists a positive and significant correlation between a positive learning environment and based creativity $[\mathrm{r}=$ $.668, \mathrm{p}<.01]$.

- The general reliability coefficient of the scale is .928 .

When these results are taken into consideration, it becomes clear that the "Creativity Based Learning Environment Assessment Scale" aimed at Major Instrument courses is a valid and reliable measurement tool.

The major results obtained with regard to the description of the learning environment in Major Instrument courses carried out in the Buca Faculty of Education, Department of Music Education are as follows:

- Measurements involving $2^{\text {nd }}, 3^{\text {rd }}$ and $4^{\text {th }}$ year students who were studying at the Buca Faculty of Education, Music Education Department during the 2014-2015 academic year, yield a reliability coefficient of .948 .

- While the response averages of guitar students to the scale were the highest with 4.55, baglama students, with an average of 2.95 gave the lowest response.

- The responses of the research group yielded a general average of 3.95; with the positive learning environment component yielding an average of 4.25 , and the creativity based component, of 3.73 .

Given these results, it can be concluded that measurements aiming to describe the creative learning environment in Major Instrument courses at the Buca Faculty of Education, Music Education Department have a high level of reliability $[.90 \leq \alpha<1]$. These courses are generally carried out in creativity based positive learning environments in which students are encouraged and supported in terms of creativity. A creative learning environment has most successfully been established in Major Instrument Guitar and least of all in Major Instrument Baglama courses. The results obtained for Baglama courses are thought to stem from the fact that courses had been carried out by externally based educational staff and in physically inadequate classrooms.

\section{References}

Buyurgan, S. ve Buyurgan, U. (2007). Sanat Eğitimi ve Öğretimi. Ankara: Pegem A Yayıncllık.

Büyüköztürk, Ş. (2009). Sosyal Bilimler İçin Veri Analizi El Kitabı. Ankara: Pegem Akademi Yayınları.

Can, A. (2013). SPSS ile Bilimsel Araştırma Sürecinde Nicel Veri Analizi. Ankara: Pegem Akademi Yayınları. 
Kaya, A., \& Bilen, S. (2016). Assessment of creativity based learning environment for major instrument courses: A case study of Buca Faculty of Education, Department of Music Education. Journal of Human Sciences, 13(2), 31023111. doi:10.14687/ihs.v13i2.3873

Çokluk, Ö., Şekercioğlu, G., Büyüköztürk, Ş. (2012). Sosyal Bilimler İçin Çok Değişkenli İstatistik SPSS ve LISREL Uygulamaları. Ankara: Pegem Akademi Yayınları.

Dokuz Eylül Üniversitesi. (2015a, January 12). Müzik Öğretmenliği Ders Katalogu. Retrieved from http://www.deu.edu.tr/rapor-ders-katalog/tr/bolum 1109 tr.html

Dokuz Eylül Üniversitesi. (2015b, January 12). Müzik Öğretmenliği Ders Katalogu Bireysel Çalg1 Dersi Tanitım Formları. Retrieved from http://www.deu.edu.tr/rapor-derskatalog/tr/bolum 1109 tr.html

Milli Eğitim Bakanlı̆̆1 (2006). İlköğretim (1- 8. Sınıflar) Müzik Dersi Öğretim Programı. Ankara: Devlet Kitaplanı Müdürlüğü.

Milli Eğitim Bakanlı̆̆1 (2009). Orta Öğretim (9- 12. Sinıflar) Müzik Dersi Öğretim Program1. Ankara: Devlet Kitapları Müdürlügü.

San, İ. (2004). Sanat ve Eğitim: Yaratıcllık-Temel Sanat Kuramları-Sanat Eleştirisi Yaklaşımları. Ankara: Ütopya.

Sungur, N. (1992). Yaratıcı Düşünce. İstanbul: Özgür Yayın- Dağıtım.

Sternberg, R. L. (1995). Defying The Crowd: Cultivating Creativity İn A Culture Of Conformity. New York: Free Press.

Yenilmez, K. ve Yolcu, B. (2007). Öğretmen Davranışlarının Yaratıcı Düşünme Becerilerinin Gelişimine Katkısı. MANAS Journal of Social Studies. Sayı.18.

Yükseköğretim Kurulu. (2007). (2015, January 12). Eğitim Fakültesi Öğretmen Yetiştirme Lisans Programları. Ankara. Retrieved from http://www.yok.gov.tr/web/guest/icerik/Ljournal content/56 INSTANCE rEHF8BIsfYRx/10279/49875 